
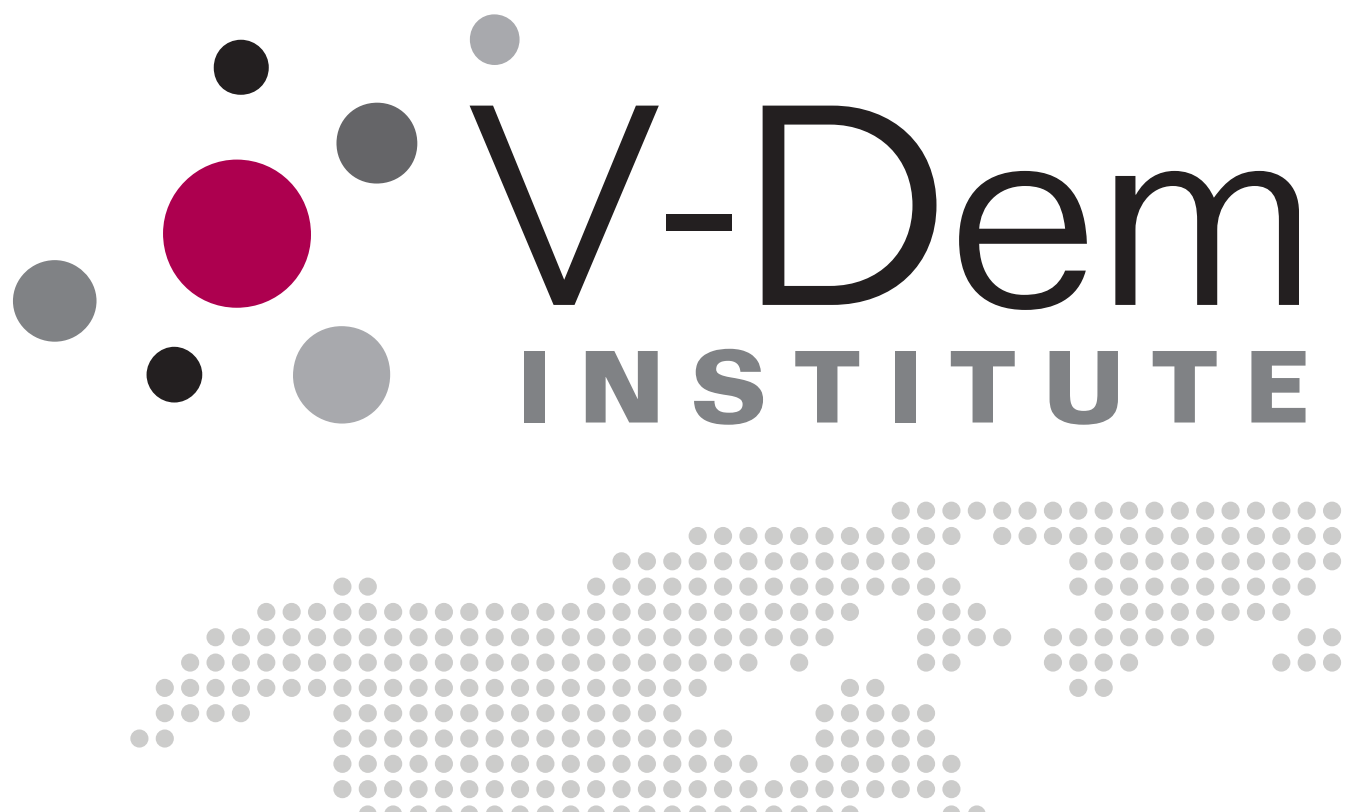

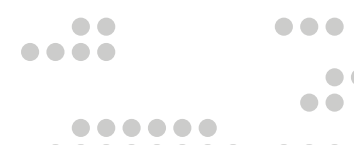
6rob

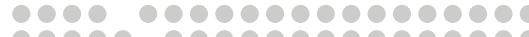

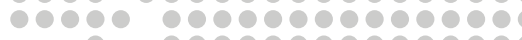

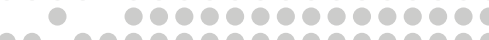
$1000 \quad 00 \quad 0000000000000000$

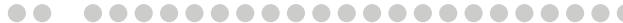

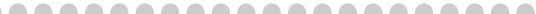

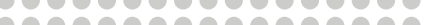
rober

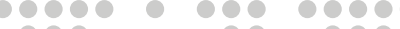

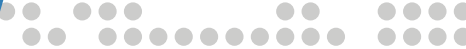

An Interactive Model of the Democratic Peace: Revisiting the Theory with Elastic Measures

David Altman, Federico Rojas-de-Galarreta, Francisco Urdinez

00000000

1000000

000000

100000

10000

000

000

10

10

80

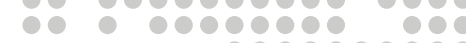

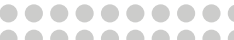

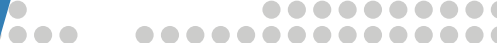
0000900009000090.080

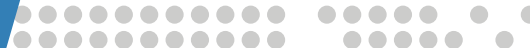

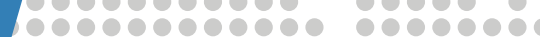

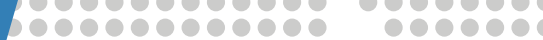

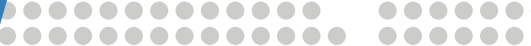

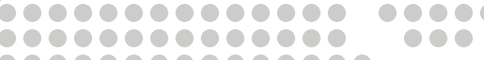

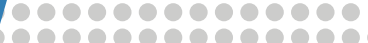

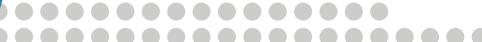

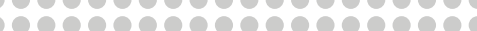

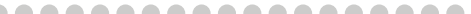

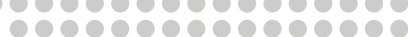
19000000000000

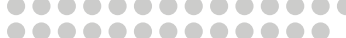
000000000000

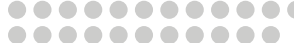
6090000000 bo000000000

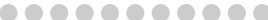
00000000000

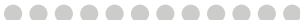
róróró 00000000 000000

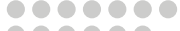

000000 000 000 :

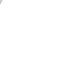

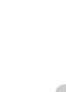

10

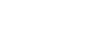


Varieties of Democracy (V-Dem) is a new approach to conceptualization and measurement of democracy. It is co-hosted by the University of Gothenburg and University of Notre Dame. With a V-Dem Institute at University of Gothenburg with almost ten staff, and a project team across the world with four Principal Investigators, fifteen Project Managers (PMs), 30+ Regional Managers, 170 Country Coordinators, Research Assistants, and 2,500 Country Experts, the VDem project is one of the largest ever social science research-oriented data collection programs.

Please address comments and/or queries for information to:

V-Dem Institute

Department of Political Science

University of Gothenburg

Sprängkullsgatan 19, PO Box 711

SE 40530 Gothenburg

Sweden

E-mail: contact@v-dem.net

V-Dem Working Papers are available in electronic format at www.v-dem.net.

Copyright (C) 2018 by authors. All rights reserved. 


\title{
An Interactive Model of the Democratic Peace: Revisiting the Theory with Elastic Measures*
}

\author{
David Altman \\ Professor of Political Science \\ Institute of Political Science/Instituto de Ciencia Política \\ Pontificia Universidad Católica de Chile
}

Federico Rojas-de-Galarreta

PhD Student

Institute of Political Science/Instituto de Ciencia Política

Pontificia Universidad Católica de Chile

Francisco Urdinez

Assistant Professor

Institute of Political Science/Instituto de Ciencia Política

Pontificia Universidad Católica de Chile

\footnotetext{
* The authors' names are listed alphabetically to reflect equal contributions to the research. We are grateful to Carsten Schulz, Nicole Jenne, Naomi Altman, and Laura Levick for helpful comments. This research project was supported by the Millennium Nucleus for the Study of Stateness and Democracy in Latin America, RS.130002; by the Riksbankens Jubileumsfond, Grant M13-0559:1, PI: Staffan I. Lindberg, V-Dem Institute, University of Gothenburg, Sweden; by the Swedish Research Council, Grant C0556201, PIs: Staffan I. Lindberg, V-Dem Institute, University of Gothenburg, Sweden; by the Knut and Alice Wallenberg Foundation grant to Wallenberg Academy Fellow Staffan I. Lindberg, Grant 2013.0166; and by the V-Dem Institute, University of Gothenburg, Sweden. V-Dem performed simulations and other computational tasks using resources provided by the Notre Dame Center for Research Computing (CRC) through the High Performance Computing section and the Swedish National Infrastructure for Computing (SNIC) at the National Supercomputer Centre in Sweden, SNIC 2016/1-382 and 2017/1-68. V-Dem Institute specifically acknowledges the assistance of In-Saeng Suh at CRC and Johan Raber at SNIC in facilitating the use of their respective systems. All caveats apply.
} 


\section{Abstract}

Democracies do not take up arms against each other. This axiom has attained the status of a mantra in the field of international relations. As previous research has shown, however, the truth of this statement is highly contingent on the definitions of both democracy and conflict. Based on this fact, this project has two aims: one empirical and one theoretical. Empirically, it revises this literature, making three substantial improvements: 1) it uses a more robust and transparent measure of democracy (V-DEM); 2) it does not rely on arbitrary cut points between democratic and non-democratic regimes; and 3) it combines the theoretical perspectives of similarity-based and normative views on the reasons behind the peace among regimes. These methodological improvements allow us to generate a new theory of democratic peace, which complements both similarity-based and institutional arguments. We find robust evidence that the higher a dyad's level of democracy, and the smaller the difference between the democratic scores of its members ('democratic spread'), the lower the probability of war (and also militarized interstate disputes, MID) between that pair of states. Thus, not only is the core principle of the democratic peace revealed to be strong enough to withstand different measures of democracy, but it also offers an alternative explanation of conflict. 


\section{Introduction}

The idea of democratic peace can be traced to the writings of Immanuel Kant, who in 1795 postulated that in a world of constitutional republics there would be no room for war (Gleditsch 1992; Brown 1999). Thomas Paine (1776) and Alexis de Tocqueville (1835-1840) also defended republics and democracies by stressing their lower propensity to war. However, it was not until the second half of the twentieth century that these ideas gained empirical traction from the pathbreaking developments made by Babst (1964), Rummel (1983), and Doyle (1986). The combination of these ideas, hypotheses, and tests is collectively known as the theory of democratic peace.

Although diverse empirical tests confirm that wars (or military conflicts) between democracies are extremely rare-to the point of being almost nonexistent (Gleditsch 1992; MaOz and Russett 1993; Gartzke 1998; Russett and Oneal 2001; Levy 2002)—a further caveat regards the views of Paine and de Tocqueville: it is not that democracies do not go to war (they do); rather, they rarely go to war against each other (Bremer 1992; Dixon 1994; Lake 1992). In other words, democratic dyads have a lower probability of experiencing militarized interstate disputes (MIDs) than other types of dyads. ${ }^{1}$ Consequently, and contrary to the assertions of Kant, the contemporary theory of democratic peace maintains that democracies are less likely to go to war with other democracies (Chan 1984; Maoz and Abdolali 1989). In fact, they go to war about as often as undemocratic states--just not with each other (Gartzke 1998; Ray 2003). ${ }^{2}$ Empirically, evidence supporting the existence of a democratic peace is so convincing that Jack Levy has claimed that the absence of war between democracies is the closest thing to an empirical law that exists in international relations (Levy 1989: 270). ${ }^{3}$

Despite the robustness of this literature, we claim that it suffers from two major flaws. First, despite being one of the most empirically tested theories in international relations - and in the discipline of political science as a whole_-virtually every such test has relied the same measure of democracy (Polity). Second, even if we assume for the moment that the concept of democracy is fully captured by this measure, almost all studies set an arbitrary cut point to distinguish between democracies and non-democracies without further justification as to why this particular point was

1 There are also monadic versions of this theory, such as Pickering (2002) or Ishiyama et al. (2008). However, they are usually not as relevant to the literature as the dyadic arguments.

2 For a discussion on Kantean peace, what Kant meant, and what he did and did not write, see Oneal and Russett (2015).

3 Likewise, Russett sustains that the democratic peace is "one of the strongest nontrivial and nontautological generalizations that can be made about international relations" (1990: 123). 
chosen along the authoritarian-democratic continuum (e.g. "0.5"). ${ }^{4}$ Yet without a theoretical reason for this choice, it is not inherently obvious where one group ends and the other begins.

This research not only makes a further step toward testing the democratic peace theory using a novel and a more robust measure of democracy (which is a contribution per se), but it also tests how far this theory travels without setting an arbitrary cut point between democracies and non-democracies. This allows us to go one-step further and build new theoretical arguments about this relationship. This is a crucial test because, as democracy has been mainly operationalized using a single indicator, the observed "democratic peace" might be an artifact of a flawed measure rather than an actual relationship among democracies. Indeed, the literature is well aware of the fact that the way democracy or war are operationalized "can play a decisive role in the testing of falsifiable hypotheses" (Bernhard et al. 2017). ${ }^{5}$ Therefore, by measuring the independent variable differently we should be able to reject this alternative hypothesis.

Conventionally, previous research into this area has examined the likelihood that two countries will go to war with each other based on their respective levels of democracy. The basic hypothesis posits that if any two countries were above a certain democratic cut point, their probability of going to war would be close to zero. Unlike previous studies that set an arbitrary cut point between democratic and non-democratic regimes, working outside a dichotomous frameset allows our theory to better capture the mixed or hybrid reality of many regimes and thereby test the elasticity of the theory. In other words, we examine how well this theory travels along the democratic continuum, not only in terms of a dyad's absolute level of democracy, but also in relation to the democratic divide between states, which refers to the absolute difference between the level of democracy of each member of a given dyad.

\section{Causal Mechanisms within Democratic Peace}

The democratic peace is probably the most discussed theory in the field of international relations. Popularly, the theory of democratic peace is usually synthesized in the following statement: democracies do not fight each other. There are two major causal explanations for the relationship between democracy and peace. The 'cultural-normative' mechanism (Russett and Oneal 2001) argues that

\footnotetext{
$4 \quad$ See Bogaards (2012) for a discussion about the use of arbitrary cut point to differentiate democracies from other type of regimes. Actually, Bogaards identifies no less than 18 different ways of using Polity to classify democracies.

5 See also Mansfield (1988) in terms of how different definitions of war affect the democratic peace literature. Also, these definitions become acutely important when extending the historical breath of the research, as contemporary definitions of democracy are extremely demanding.
} 
democratic societies are inherently reluctant to go to war because: 1) citizens do not vote to send themselves to war; and 2) democracies share the basic principle of peaceful conflict resolution, which extends to their relationships with other countries (Levy 2002: 359). This mechanism has been strongly criticized (Rosato 2003) and is slowly falling into disuse, being replaced by an institutional (and not normative) version.

The institutional version of the democratic peace is based on 'institutional constraints' (Levy 2002: ibid) and emphasizes structural elements rather than rules. Such elements include: the formal and informal vetoes that may exist, the checks and balances between the powers of the State, and, more generally, the dispersion of power and the role of the free press. According to this model, decision makers are constrained by the need for popular support, dispersed in various government institutions (Russett 1994: 38). Recently, Hegre et al. (Forthcoming) have developed new tests that refine the mechanisms of institutional constraint, differentiating between those that are formally vertical (elections), informal (civil society activism), and horizontal (the constraints that other branches place on the Executive).

Given its prominence within the field, the theory of democratic peace has been challenged on numerous counts. On the one hand, it has been argued that the causal relationship between the two is spurious (Rosato 2003; Mousseau 2009, 2013), driven instead by international institutions, geographic distance, political and military alliances, economic interdependence, political stability or state capacity (Russett 1994). On the other hand, a stronger criticism holds that it is not democracy that causes peace, but the similarity between regimes (Raknerud and Hegre 1997; Gartzke 1998, 2000; Werner 2000; Peceny et al. 2002; Lektzian and Souva 2009). This reasoning assumes that those regimes that are similar to each other in terms of their democratic level have a lower probability of conflict than mixed dyads, which applies to both the subset of democratic states as well as the subset of autocratic states.

The similarity argument derives from the fact that democratic states do not fight each other, but that does not mean they do not fight other types of states. ${ }^{6}$ In this way, both Gleditsch \& Hegre (1997) and Raknerud \& Hegre (1997) hypothesize that the probability of war in a mixed dyad must be greater than the probability in a similar dyad, be it democratic or autocratic. Likewise, Werner (2000) argues that similar states are less likely to enter into conflict than disparate states, testing this view with an analysis of the survival of peace duration in similar and mixed dyads.

As suggested by Blaney (2001), democracies co-exist only very uneasily with non-democratic regimes. From his view, democracies are intolerant with autocracies, and therefore "troublemakers." This is because democracies usually sanction autocracies, denounce violations of basic human rights, etc. On this point, see also Barkawi and Laffey (1999). 
Their results show that politically akin dyads are more likely to enjoy a lasting peaceful relationship over time, even controlling for the democratic character of those states. The dyads of democratic states remain the most peaceful, but even the dyads of autocratic states are notably more peaceful than mixed dyads.

Gartzke $(1998,2000)$ explores a parallel argument, hypothesizing that it is the similarity of states' preferences that causes peace, and not the democratic character of those states. In his words: "If similar regime type leads to similar preferences, then we have not to 'democratic peace' so much a 'regime type similarity peace"' (Gartzke 1998: 11). After his analysis, the author concludes that much of what has been described as 'democratic peace' can be explained by the similarity of national preferences between states. Peceny et al. (2002) disaggregate the category of autocracies into several subsets and argue that the similarity in the type of autocracy presents a lower probability of conflict compared to mixed dyads, but higher than in the case of democratic dyads. After constructing a theoretical model based on political similarity, geographical distance and economic interdependence, Henderson (2002) is also strongly critical of the theory of democratic peace. In a synthetic way, he maintains that democratic peace is only a statistical artifact, which disappears when these other variables are taken into account. Following a similar intuition, Bennett (2006) tests a multinomial logit model that classifies states into democratic, autocratic or mixed dyads. Taking the mixed dyads as a base category, the result confirms that the autocratic dyads have a $35 \%$ lower chance of conflict and the democratic dyads a 55\% lower chance of conflict. However, if only wars are considered, which represent the highest level of militarized conflict, the effect dilutes: democratic dyads have $82 \%$ less chance of going to war than autocratic dyads. A different line of argument follows Lektzian \& Souva (2009), who explore the consequences of a 'regime-similarity peace' for the different versions of the theory of democratic peace.

Conversely, the cultural-normative mechanism of the theory of democratic peace assumes that there is something inherently different in the relations between democratic states that are not present in the relationship between autocratic states, which have very different institutional constraints. For this reason, it can hardly be complemented with arguments such as regime similarity. In the words of Letzkian \& Souva:

if there is a broader regime-similarity peace, then the theory of the democratic peace based on similar institutions leading to a shared set of preferences for international outcomes would have significant excess empirical content over established theories of the democratic peace based on information or norms (2009: 17). 


\section{Explaining the Rationale of the Interactive Model of Democratic Peace}

Despite their many differences, the institutional constraints explanation and the 'similarity-based peace' (also known as isomorphic peace) are complementary in several respects. The perspectives are not the same: democratic peace holds that institutional constraints that reduce the likelihood of conflict are found only in democracies, while autocratic peace holds that they can also be present in autocratic states. Nonetheless, their causal logic is not entirely opposed, as in the case of the cultural-normative mechanism. The autocratic peace argument, in its 'soft' version, tries to explain why autocratic dyads have a lower probability of conflict than mixed dyads, an empirical fact that has already been observed by the theorists of democratic peace (Bremer 1992; Hewitt and Wilkenfeld 1996). Authors in this tradition argue that institutional constraints are not unique to democratic states, but are also present (to some degree) in a wide range of autocracies. Checks and balances, veto players and the need to mobilize popular support are also present in many autocracies - a fact that underscores the need to exercise caution when operationalizing 'democracy.'

Based on the complementary characters of the cultural-normative perspective (democracies do not fight each other because they have a distinctive character) and the similaritybased view (similar regimes do not fight each other because of shared interests), Figure 1 depicts an interactive effect between both mechanisms. This figure illustrates every possible dyad based on each country's democratic level and the democratic difference within each dyad.

Figure 1 shows four hypothetical dyads of countries (a, b, c, d), along two axes: the democratic level of the dyad and its democratic spread. The dyad "a" has a combined level of democracy of 0.9 due to the democratic scores of its members $(|1.0|-|0.8|)$; the spread-or absolute difference between the democratic scores of both members—is $0.2(|1.0|-|0.8|)$. Likewise, dyad "b" has a democratic mean of 0.15 and a spread of 0.1 given by the values of each country $(|0.1|-|0.2|)$. Dyad "c" has a democratic level of 0.675 and a spread of 0.4. Finally, dyad "d" has the broadest spread of these examples of $(0.7)$ due to its member values $(|0.05|-|0.75|)$ and a combined democratic mean of 0.4 . 


\section{Figure 1. Dyad's Democratic Mean and Spread}

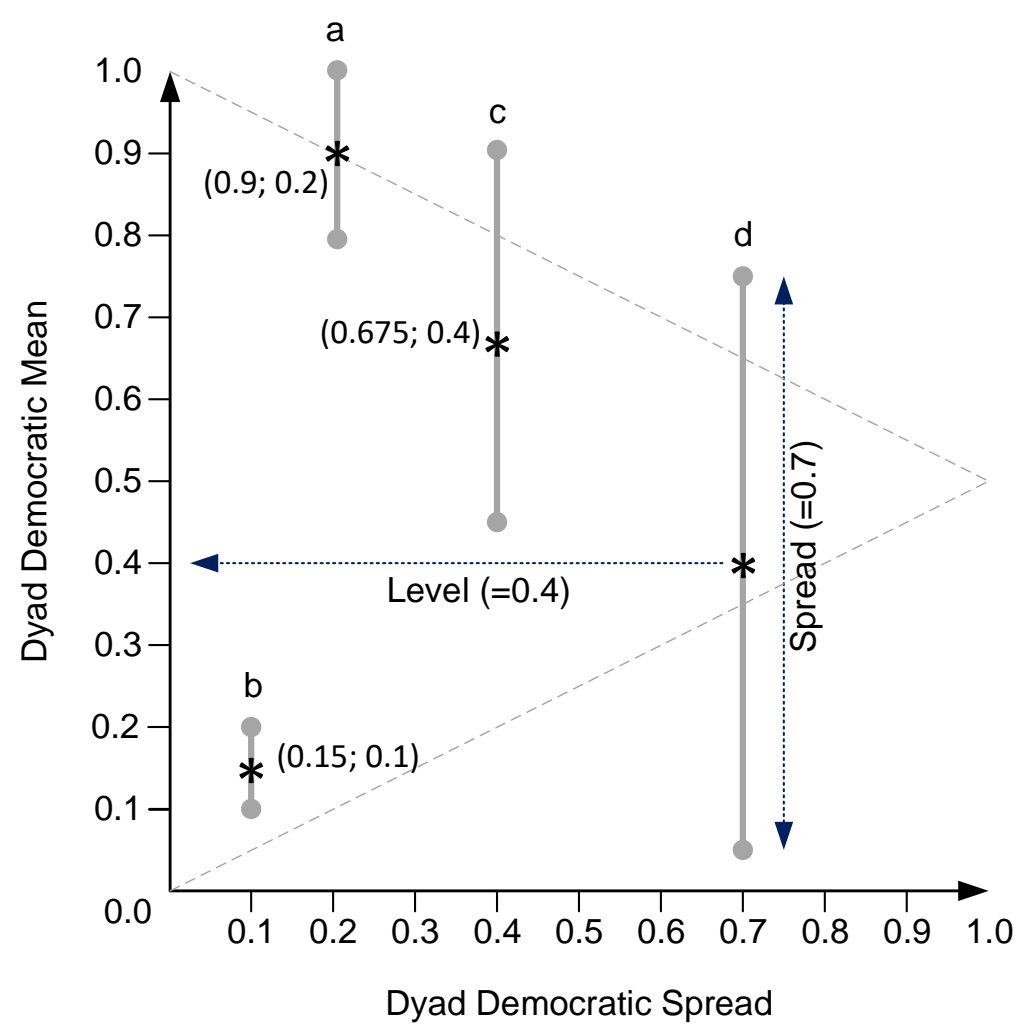

Whether because it is of its high democratic level or its minimal democratic spread, virtually all students of the democratic peace-regardless of their theoretical stand-will agree that dyad "a" is one with the lowest probability of conflict. In dyad "b", both members are clearly nondemocratic, which means that the likelihood of conflict should be larger than in dyad "a," at least from an institutionalist perspective. From a similarity-based view, the members of this dyad are even more similar than those in dyad " $a$ " $\left(\operatorname{spread}_{a}>\operatorname{spread}_{b}\right)$, therefore the probability of conflict should be even lower than in "a." Dyad "d" is certainly the most conflict-prone group of all, as it is composed of a democratic regime and an unambiguously authoritarian regime, with a large concomitant difference. Of course, these are simple examples for the sake of explanation; for any given democratic level, there are an infinite number of dyadic pairs whose spreads will differ.

Theoretically speaking, the dyad with the broadest possible spread is the pairing in which one member has a democratic score of one, while the other has a score of zero. By definition, this dyad cannot have a combined democratic average of anything other than 0.5 . Thus, there is a dyadic triangle — drawn by the dashed lines - that circumscribes the arena where all potential imaginable dyads can be found. (Please note that this triangle refers to the characteristics of the dyad, not countries forming the dyad.) 
Building on the graphical description of dyad means and spreads in Figure 1, Figure 2 represents the expected regions of peace and conflict based on the literature discussed above. Figure $2 \mathrm{a}$ depicts the expectation of the original idea that democracies do not fight each other, following Singer \& Small (1974). Thus, the circle in the upper left shows the anticipated region of peace based on the institutionalist perspective (dyads composed of quite similar and highly democratic countries). Figure $2 \mathrm{~b}$, however, sketches the similarity-based view. There is a peace zone concentrated vertically at the left of the dyadic triangle, encompassing those regimes that are notably similar (very low spread) in terms of their democratic level, regardless of the absolute value of the level itself. At the far right of the dyadic triangle, there is a region of conflict, which by definition involves extremely different regimes.

Thinking of this orthogonal space delimited by the democratic mean and spread of each dyad is congruent with a certain part of the literature, but differs in the evident avoidance of a clear cut-off point between democracies and non-democracies. This is a major departure from all the aforementioned approaches. Working with pairs of binary variables (i.e. democracy vs. nondemocracy), outcomes are logically restricted to a $2 \times 2$ matrix, which limits possible combinations and other types of relationships. Working with a continuous measurement of democracy has the benefit of being able to identify variation in the effect along the democratic continuum, without theoretically presupposing it in advance. Also, it opens the door to the possibility that the effect of the level of democracy varies conditionally by the democratic spread of both countries or vice versa, without ruling out in advance the potential existence of causal heterogeneity. This allows us to better approach certain cases that are part of the 'gray area' in which defining a regime as democratic or non-democratic is difficult.

Taking advantage of continuous measurements of democracy, we agree that there is an uneasy relationship between democracies and autocracies. Democracies use a diverse range of tools to (sometimes forcibly) democratize autocracies. Contrary to the similarity-based perspective, we find the argument of shared interests among autocracies to be unpersuasive. Of course, that is not to say that autocracies do not have internal institutional constraints-they clearly do (Castiglioni 2001; Gandhi 2008)—but the creation of a common external enemy is old as time itself.

Thus, using Figure 1 as a hypotheses generator, we expect that the lower a dyad's average level of democracy and larger its democratic spread, the higher the probability of a war between its component states. This is to say, we expect wars to occur close to the lower side of the triangle previously described, in what we term the "risk region." Likewise, the mirror image of the hypothesis, the higher a dyad's level 
of democracy and smaller its democratic spread, the lower the probability of a war between its component states, leads us to anticipate a "zone of peace." Both zones are depicted in Figure 2c. Our theory is heir of the "peace scale for State relationships" elaborated by Goertz et al. (2016: 27). They suggest three groups of indicators that produce three categories: Rivalry, Negative peace, and Positive Peace, respectively.

Obviously, the fact that a dyad is located close to the lower side of the triangle, within the risk region, is not sufficient for a war to occur. Indeed, many thousands of countries in that region coexist peacefully without ever exhibiting even the slightest signal of aggression toward one another (e.g. Cuba and Nepal in 1980). Therefore, we cannot forget that we are working with a probabilistic hypothesis. Likewise, the fact that a dyad is located outside the risk zone does not mean that the probability of a war is zero; in reality, some wars clearly occur beyond the risk region (e.g. Poland-Lithuania in 1920 or Turkey-Cyprus 1974, etc.). Although a couple of cases in a universe of several hundred thousand cases do not invalidate a theory (King et al. 1994), they do compel a more detailed and nuanced elaboration. In due time we will tackle the cases outside the risk region previously mentioned.

\section{Figure 2. Theories of the Democratic Peace based on Dyad's Democratic Mean and Spread}

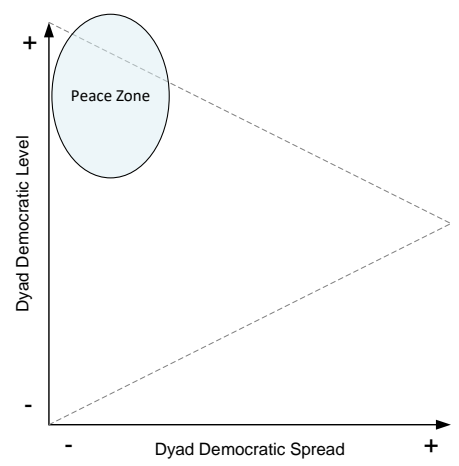

(a) The Traditional Democratic Peace

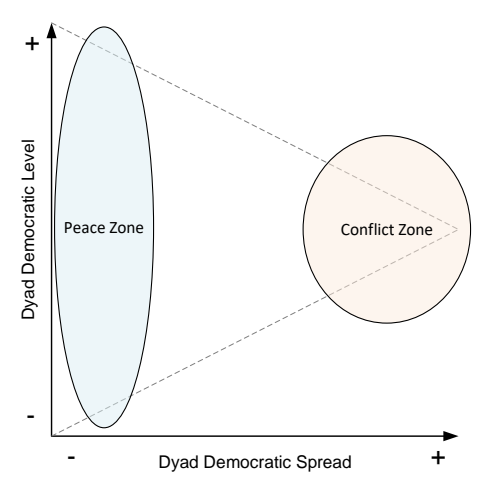

(b) The Similarity-Based Views of Democratic Peace

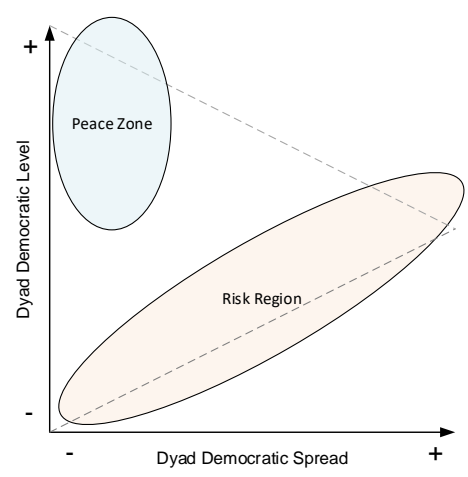

(c) The Interactive Model of Democratic Peace 


\section{Research Design: Variables and Methods}

\section{Dependent variable: $W$ ar}

It is abundantly clear that the different ways in which conflict is operationalized have a clear impact on any study of the democratic peace. Different definitions result in the inclusion or exclusion of particular cases, thereby altering the results. Moreover, even agreeing on what constitutes 'democracy' and 'war' may prove controversial. For example: 'By Doyle's definition, Spain only became a liberal regime in 1978, but Lake's article, making use of the Polity II data set, codes Spain as democratic in 1898" (Spiro 1994: 60). He adds: "because the literature on democracy and war is highly empirical, it is important to remember that the subjective judgments by which variables are coded in data sets have significant and important effects on the results yielded by analysis of those data" (Spiro 1994: 62).

Because war is (thankfully) a rare occurrence, the literature testing the democratic peace theory has mostly used MIDs as a dependent variable, which includes a greater range of conflict than just war (Bremer et al. 1972; Jones et al. 1996). These are situations

in which the threat, display or use of military force short of war by one-member state is explicitly directed towards the government, official representatives, official forces, property, or territory of another state. Disputes are composed of incidents that range in intensity from threats to use force to actual combat short of war (Jones et al. 1996, 168).

In addition to full-blown war, MIDs also include threats, signs of force, and more limited use of force. It is worth noting that the term 'militarized interstate dispute' only applies to conflicts between internationally recognized sovereign states; therefore, conflicts within countries (e.g. Syria at present), colonial wars (Algeria v. France), or armed conflicts involving non-state actors (FARC v. Colombian State) are excluded from the analysis. From this perspective, war is a subset of MIDs. The concept of war commonly refers to the use of lethal violence, institutionally organized, and on a large scale (Russett 1994: 12).

While previous works-e.g. Maoz (1999), Gartzke (2000), Bennett (2006), Lektzian and Souva (2009), Gartzke \& Weisiger (2013)—have coded MIDs in a 'broader sense' [ where 1 is a dispute and 0 is the absence of a dispute], we use a more restrictive codification in which 1 is a war and 0 otherwise. ${ }^{7}$ Our choice is based on Goertz (2017), who tackles one of the major discussions

Overall, $99.9 \%$ of the dyads are coded as 0 , and $0.1 \%$ as 1 , totaling 583 dyads at war between 1900 and 2000 . The data is retrieved from the Correlates of War project, and our variable is a transformation of the ordinal variables Hostlev A and HostlevB: (1) No militarized action; (2) threat to use force; (3) display use of force; (4) 
of this literature:

Using the example of the democratic peace, one needs to go back to the main dependent variable under consideration: Is it "war" or "peace"? The dependent variable in virtually all large-N statistical studies is militarized interstate disputes (aka MIDs). This means that peace is conceptualized as "not-MID." This is problematic: for example, the USA and North Korea have not been at peace for most years since 1955, but rather they have been in a state of not-MID.

The sufficient condition version of the democratic peace-the most popular one-is problematic exactly because of the problematic conceptualization of peace as not-war. The sufficient condition version in practice is explaining "not-war" or "not-MID." This is a heterogeneous category. In many studies, "peace" includes (1) years of peace between the USA and Canada, (2) years of not-MID between serious rivals such as India-Pakistan or the USA-USSR, and (3) years of no interaction such as Chile-Cameroon (see Goertz, Diehl, and Balas 2016 for a discussion of the concept of peace). Arguably, the causal mechanisms producing these three "not-MID" zero cases are quite different. In contrast, the necessary condition version focuses on the dependent variable of militarized disputes and wars (2017: 112).

We use two ordinal variables from Correlates of $W$ ar that include several degrees of MIDs to test the robustness of our findings. The first of them is comprised of the five categories in Hostlev $\mathrm{A}$

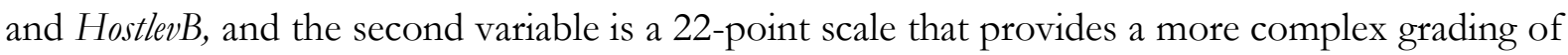
conflicts. Table 1 expresses the codification of the three different operationalization of the dependent variable we consider.

use of force; and (5) war. Our dummy for wars only considers, then, category (5) as a positive outcome. Out of the 606,056 dyads that the dataset has for the period $1900-2000,99.38 \%$ correspond to category (1), $0.2 \%$ to category (2), $1.1 \%$ to category (3), $3.9 \%$ to category (4) and $0.1 \%$ to category (5). This totals 583 wars out of 606,056 observations. 
Table 1: Codification of the Dependent Variable

\begin{tabular}{|c|c|c|c|}
\hline Type of conflict & $\begin{array}{c}\text { dependent } \\
\text { variable }\end{array}$ & $\begin{array}{c}\text { robustness check } \\
\text { 1: MID (a) }\end{array}$ & $\begin{array}{c}\text { robustness check } \\
\text { 2: MID (b) }\end{array}$ \\
\hline No militarized action & 0 & 1 & 0 \\
\hline Threat to use force & 0 & 2 & 1 \\
\hline Threat to blockade & 0 & 2 & 2 \\
\hline \multicolumn{4}{|l|}{ Threat to occupy } \\
\hline territory & 0 & 2 & 3 \\
\hline Threat to declare war & 0 & 2 & 4 \\
\hline \multicolumn{4}{|l|}{ Threat to use CBR } \\
\hline weapons & 0 & 2 & 5 \\
\hline Threat to join war & 0 & 2 & 6 \\
\hline Show of force & 0 & 3 & 7 \\
\hline Alert & 0 & 3 & 8 \\
\hline Nuclear alert & 0 & 3 & 9 \\
\hline Mobilization & 0 & 3 & 10 \\
\hline Fortify border & 0 & 3 & 11 \\
\hline Border violation & 0 & 3 & 12 \\
\hline Blockade & 0 & 4 & 13 \\
\hline Occupation of territory & 0 & 4 & 14 \\
\hline Seizure & 0 & 4 & 15 \\
\hline Attack & 0 & 4 & 16 \\
\hline Clash & 0 & 4 & 17 \\
\hline Declaration of war & 0 & 4 & 18 \\
\hline Use of CBR weapons & 0 & 5 & 19 \\
\hline Begin interstate war & 1 & 5 & 20 \\
\hline Join interstate war & 1 & 5 & 21 \\
\hline
\end{tabular}

Source: Correlates of War. 


\section{Independent Variables: Dyadic Democratic Mean and Spread}

The vast majority of recent studies on democratic peace use Polity as an indicator of democracy. ${ }^{8}$ This measure is in itself quite problematic (Munck and Verkuilen 2002; Coppedge et al. 2011). This is due to two reasons: 1) Values must be accepted at face value (since they cannot be replicated), but also 2) Because it is an ordinal variable that is routinely treated as continuous. ${ }^{9}$ Of course, we are well aware that until very recently Polity was the only truly cross-national and longitudinal database available to researchers; a situation that has drastically changed since the release of V-DEM's database. ${ }^{10}$

V-DEM's data are compiled by experts in each country, through questions with welldefined response categories or scales of measurement. Ideally, at least five experts contribute to each indicator for each country-year. This means that more than 2,600 experts in total have participated in the data collection. At the same time, the individual expert scores are aggregated using a Bayesian IRT model, which produces an estimate of the latent variable for each indicator (Coppedge et al. 2017). Likewise, its continuous nature (the variable ranges from 0 to 1 ) does not assume a fixed boundary between democracy and non-democracy, taking into account the variations in the effect depending on the value that the independent variable takes. In this way, the non-linearity proposed by the logit models is used (Long 1997; Agresti 2007).

The electoral democracy index used here (v2x_polyarchy) is the basis for all indices of democracy developed by V-DEM. It takes as reference the concept of polyarchy developed by Dahl $(1971,1989)$. This variable is understood as a core element of any other conception of representative democracy: liberal, participative, deliberative, egalitarian or other (Coppedge et al. 2016a). The index is formed taking the average of: 1) The weighted average of the indexes that measure freedom of association, suffrage, free elections, elected executive, and freedom of expression; and 2) The multiplicative interaction between these five indices.

Based on V-DEM's polyarchy index, we calculate the democratic mean and democratic spread for each dyad-year between 1900 and 2000. Democratic Mean refers to the average of both member of the dyad polyarchy measures, and Democratic Spread is determined by the absolute difference between the democratic values of each member of the dyad. Democratic Spread is

\footnotetext{
8 Previous studies also used dichotomous indicators of democracy and non-democracy (Babst 1964; Doyle 1986).

$9 \quad$ On the problems of using discrete indicators as if they were continuous, see Long and Freese (2006).

$10 \quad$ For an overview of V-DEM see Coppedge et al (2011), and for further details on the construction of high level indices using V-DEM data, see Coppedge et al (2016b).
} 
therefore a direct heir of the dyadic difference measure proposed by Gartzke \& Weisiger (2013) based on Polity. The interplay of these two variables creates a set of finite possibilities which we define as the dyadic triangle, as described in Figure 1. ${ }^{11}$ (See Figure A1 at the online appendix for a graphical distribution of these variables for all our observations.)

\section{Control Variables}

The control variables included in our model follow the relevant literature, and correspond to potential alternative explanations for the relationship between democracy and conflict.

- Geographical distance and contiguity. It is based on the assumption that neighboring countries are more likely to experience conflict than distant countries. This is measured through two variables: a) Contiguity, which takes value of 1 when they are contiguous and 0 when they are not; and (b) Distance, which is the natural logarithm of the number of miles between the two capital cities in the dyad. ${ }^{12}$ Incorporating distance allows for the differentiation between the effect of proximity and preferences (Hensel 2000; Senese 2005).

- Alliance. It is based on the assumption that the existence of an alliance has an effect on the likelihood of conflict. This variable dummy codes the presence of a defense pact, neutrality pact or entente in the dyad as 1 , and the absence of these pacts as 0 , using the Alliances database of the Correlates of War project (Singer and Small 1966; Small and Singer 1969; Gibler 2008).

- Proportion of material capacities. It is based on the assumption that material capabilities determine the ability of States to carry out an armed conflict. This is typically measured using the Composite Index of National Capabilities, or simply CINC (Singer 1988). This index incorporates an average of six indicators: military spending, military personnel, energy consumption, iron and steel production, urban population, and population size (as a proportion of world's population). In turn, the proportion of material capacities used here measures the sum of the CINC in the dyad, expressed as a percentage.

- Great power. It is based on the assumption that the great powers have a greater probability

If one observes the evolution of the polyarchy means and spread between 1900 and 2000, it is clear that both variables are correlated in time and that after 1989, when the Cold War ended, the average polyarchy score has increased while the difference has remained unchanged, showing that there has been a democratization wave. This same trend is observable in 1945, 1919 and 1901 (see Figure A2 at the appendix). 
of conflict than the non-powers. The Great Power variable is coded as 1 if at least one of the States in the dyad is a power and 0 if no State in the dyad is a power, according to the criteria followed by Correlates of War (Singer 1988).

- Trade interdependence. In order to include one of the main alternative explanations for democratic peace, studies typically include a measure trade dependence for each dyad, which results from the sum of the dependence of both countries on trade. This variable has a large amount of missing values (the periods of 1914-1919, 1939-1945 and 1993-2000), so the literature usually includes it only as a robustness check (Gartzke and Weisiger 2013). We create one variable using the trade dependence variable as suggested by Oneal \& Russett (1997) and discussed by Barbieri and Peters (2003) that we name trade interdependence, which measures the average trade interdependence growth rate in the dyad, expressed as a percentage.

- Time autocorrelation. There are three ways to address time dependence in binary data: one could use splines or time dummies, both of which are addressed by Beck, Katz, and Tucker (1998), or include $t, t^{2}$, and $t^{3}$ in the regression, as suggested by Carter and Signorino (2010). We opted for the latter alternative, as it is much easier to implement than splines and avoids the problem of quasi-complete separation of time dummies.

\section{Statistical Analyses}

The democratic peace theory has been refuted and resurrected many times in recent years due to measurement decisions and methodological misspecifications (Gartzke 2007; Dafoe 2011; Dafoe et al. 2013; Mousseau 2013). Two main objections have been raised to the causal inference: peace may cause democracy, or some other societal factors may cause both democracy and peace (Hegre 2014: 163). Because our contribution is to test an alternative measure of democracy, which we believe has many advantages over previous studies, our control variables are those most frequently found in the literature. We do not dig, for instance, in the democratic peace-capitalist peace debate, which would require an extensive array of economic variables. We aim to offer a model as parsimonious as possible to explore the interplay between democratic mean and democratic spread in country dyads. After we run several robustness checks, we proceed to a discussion on which threshold of democratic mean/spread is a necessary condition to achieve peace, ceteris paribus, and discuss a few enlightening cases as suggested by Levy and Goertz (2007). 
Our universe of analysis is constituted by approximately 365,000 observations. Although democratic mean and democratic spread have around 480,000 observations each, trade exhibits 365,000 observations. Our models remain notably robust even without including the variable trade.

Our baseline model can be specified as

$$
\begin{aligned}
\operatorname{Pr}(\text { War })_{\mathrm{i}, \mathrm{t}}= & \beta_{0}+\beta_{1} \text { DemMean }_{\mathrm{i}, \mathrm{t}}+\beta_{2} \text { DemSpread }_{\mathrm{i}, \mathrm{t}}+\beta_{3} \text { Contiguity }_{\mathrm{i}} \\
& +\beta_{4}(\log ) \text { Distance }_{\mathrm{i}}+\beta_{5} \text { Alliance }_{\mathrm{i}, \mathrm{t}}+\beta_{6} \text { CINC }_{\mathrm{i}, \mathrm{t}}+\beta_{7} \text { GreatPower }_{\mathrm{i}, \mathrm{t}} \\
& +\beta_{8} \text { TradeInterdependence }_{\mathrm{i}, \mathrm{t}}+\beta_{9 \ldots 11} \text { TimeAutocorrelation }_{\mathrm{i}, \mathrm{t}}
\end{aligned}
$$

Where subscript $i$ denotes the dyad and $t$ the year. We include standard errors clustered by dyad.

As seen in Table 2, Model 1 uses a logit model with a dichotomous indicator of war as the dependent variable. We then use the ordinal MID variables, first the five-category variable and then the 21-category variable (see Table 1) in Models 2 and 3, respectively. Our main interest is in the interplay between dyad democratic spread and dyad democratic mean. Results are notably robust across all models and according to our expectations. Democratic mean is negatively associated to the probability of war occurrence, while spread is positively so. Of all the controls included in the specifications, only the inclusion of a major power in a dyad did is statistically discernable from zero in all models. Contiguity also is not statistically different from zero in Model 1, the logit model. $^{13}$

13 We performed the correction for the occurrence of rare events (rare events) as proposed by King \& Zeng (2001). As stated by King \& Zeng (2001), when working with binary dependent variables that have many 'zeros' and very few 'ones'there is a risk that the probability of occurrence of the event will be underestimated. For this, the authors propose a correction of the bias produced in the estimation. Knowing the probability of 'ones' that there is in the pobado this bias can be corrected by means of the method of prior correction. The results do not differ substantially from those reported in the model 1 (see Table A in the appendix). 
Table 2: War and MIDs

\begin{tabular}{|c|c|c|c|}
\hline \multirow[b]{2}{*}{ Dependent variable: } & (1) & (2) & (3) \\
\hline & \multirow[t]{2}{*}{ war } & MID (a) & MID (b) \\
\hline & & Ordered & Ordered \\
\hline Model: & Logit & logit & logit \\
\hline \multirow[t]{2}{*}{ Democratic Mean } & $0.958^{* *}$ & $0.982^{* * *}$ & $0.982 * * *$ \\
\hline & $(-2.61)$ & $(-6.15)$ & $(-6.11)$ \\
\hline \multirow[t]{2}{*}{ Democratic Spread } & $1.030 * * *$ & $1.019 * * *$ & $1.018^{* * *}$ \\
\hline & $(3.79)$ & $(9.76)$ & $(9.82)$ \\
\hline \multirow[t]{2}{*}{ Trade interdependence } & $0.947 * *$ & $0.946^{* * *}$ & $0.946 * * *$ \\
\hline & $(-3.01)$ & $(-4.55)$ & $(-4.65)$ \\
\hline \multirow[t]{2}{*}{ Contiguity } & 2.228 & $17.02^{* * *}$ & $16.16^{* * *}$ \\
\hline & $(1.24)$ & $(20.47)$ & $(20.17)$ \\
\hline \multirow[t]{2}{*}{ Distance $(\log )$} & $0.715^{* *}$ & $0.848^{* * *}$ & $0.843^{* * *}$ \\
\hline & $(-2.98)$ & $(-10.86)$ & $(-11.11)$ \\
\hline \multirow[t]{2}{*}{ Material Capabilities } & $599.9 * * *$ & $23495.6^{* * *}$ & $20235.9 * * *$ \\
\hline & $(3.48)$ & (13.61) & $(13.69)$ \\
\hline \multirow[t]{2}{*}{ Alliance } & $0.111 * * *$ & $0.597 * * *$ & $0.601 * * *$ \\
\hline & $(-4.55)$ & $(-5.49)$ & $(-5.40)$ \\
\hline \multirow[t]{2}{*}{ One is a Major Power } & 0.941 & 1.089 & 1.091 \\
\hline & $(-0.11)$ & $(0.65)$ & $(0.66)$ \\
\hline \multirow[t]{2}{*}{$t$} & 1.482 & 0.978 & 0.981 \\
\hline & $(0.62)$ & $(-0.58)$ & $(-0.51)$ \\
\hline \multirow[t]{2}{*}{$t^{2}$} & 0.995 & 1.001 & 1.001 \\
\hline & $(-0.47)$ & $(1.89)$ & $(1.80)$ \\
\hline \multirow[t]{2}{*}{$t^{3}$} & 1.000 & $1.000^{* *}$ & $1.000 * *$ \\
\hline & $(0.29)$ & $(-2.89)$ & $(-2.80)$ \\
\hline AIC & 2594.6 & 16907.1 & 20006.6 \\
\hline Pseudo $R^{2}$ & 0.173 & 0.249 & 0.219 \\
\hline$\% \mathrm{CP}$ & $99 \%$ & $52 \%$ & $48 \%$ \\
\hline $\mathrm{N}$ & 303800 & 303800 & 303800 \\
\hline
\end{tabular}

Coefficients expressed as odds ratios; Standard errors clustered in dyads t statistics in parentheses; ${ }^{*} \mathrm{p}<0.05,{ }^{* *} \mathrm{p}<0.01,{ }^{* * *} \mathrm{p}<0.001$ 
At this point, the reader will ask why there is not an interaction term between our two crucial independent variables, democratic mean and democratic spread. The discussion about the need to incorporate interaction terms in logit models is still an open one. There are authors who argue that it is not necessary to incorporate it since it is present by definition in this type of model (Berry et al. 2010). On the contrary, there are also authors who have recently argued in favor of their inclusion (Rainey 2016). In this case we do not include it, following Berry et al. (2010), who see interactions as a result of compression. ${ }^{14}$

To interpret the interaction, we created a figure of the predicted probabilities in all the possible combinations of our two variables of interest, keeping all other variables at mean levels (see Figure 3). We are offer a heuristic aid based on the probabilities of war, which overwhelmingly supports our theoretical expectation represented graphically in Figure 2c. Combining the probabilities estimated and the empirical distribution of cases, it is evident that the risk zone is constituted by the trapezoid along the lower bound of the triangle formed by democratic spread and democratic mean.

\section{Figure 3: Predicted Probabilities of War from Model 1}

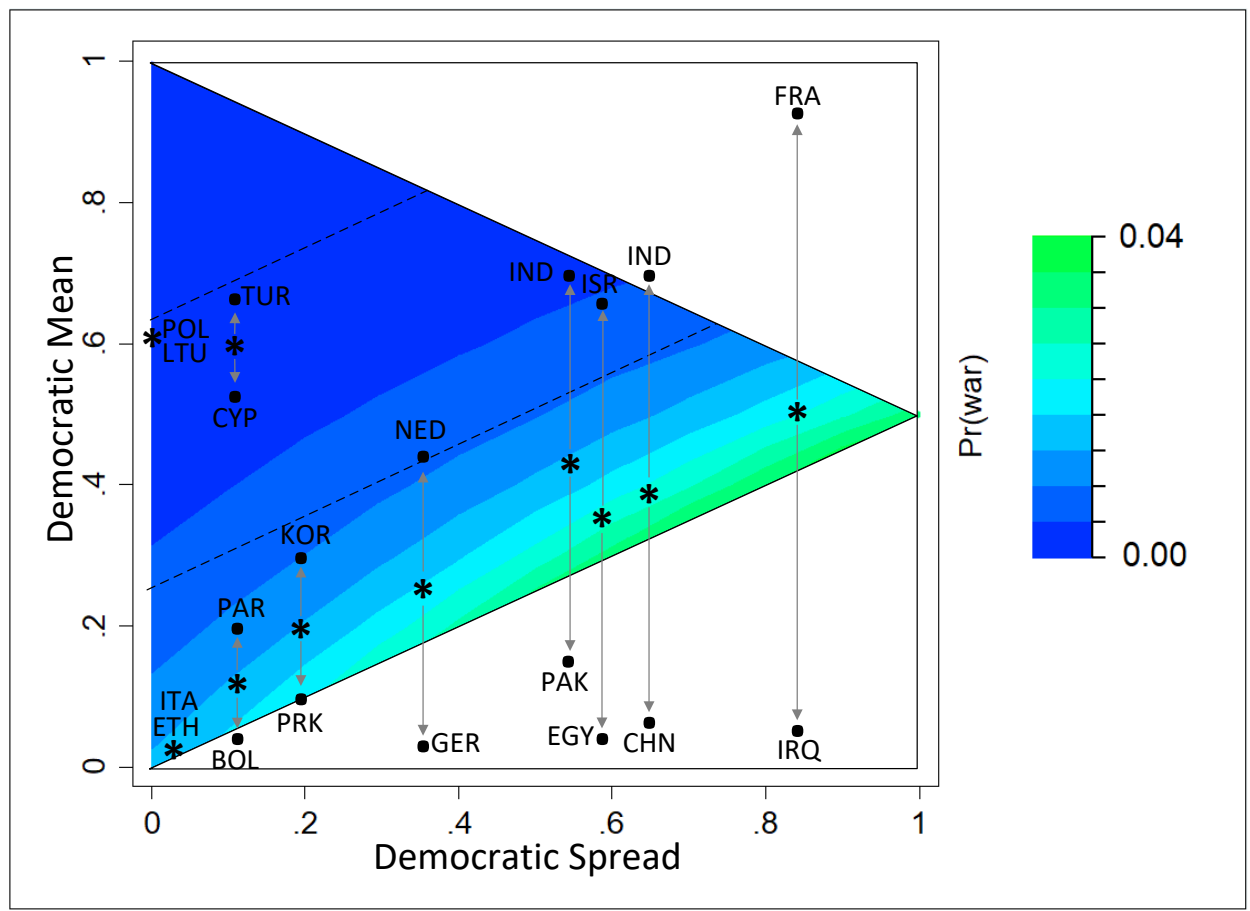

"Compression is present in a logit or probit model because as $\operatorname{Pr}(\mathrm{Y})$ approaches its limits of 1 and 0 , even powerful causal variables cannot increase/decrease the probability of an event beyond the upper/lower limit that probabilities can assume" (2010: 254). 
The figure above combines the probabilities of war based on Model 1 with real examples of wars using exemplary cases. ${ }^{15}$ For a complete view of the distribution of all dyads and all dyads at war, see Figure A3 in the appendix. ${ }^{16}$ We illustrate the probability of war: the lighter the color, the higher the probability of war. We have also indicated select examples of war using a star, which represents the dyad location in both crucial dimensions explained above (democratic mean and democratic spread). For a better understanding of this figure, we also include the democratic level of each country belonging to the selected cases. As hypothesized, there is a risk area (area under the lower bound) and a peace zone (above the upper bound), which can serve as rules to predict war among states.

Of all dyads in the analysis, the dyad with the broadest democratic spread was during the Gulf War between France and Iraq in 1991. To the contrary, the dyad with the highest democratic mean that went to war is that of Poland and Lithuania in 1920 (well outside the risk zone), and the one with the lowest democratic mean of them all is the dyad composed of Italy and Ethiopia in 1936.

As explained from the beginning of this research, we explicitly avoid setting a cut point between democracies and non-democracies. Nonetheless, a view of the very few cases that fall well beyond the risk zone (such as the Polish-Lithuanian war of 1920, or the Turkish-Cypriot conflict of 1974, the two dyads with the highest democratic means) seem to be an explicit challenge to the democratic peace theory. We contest this interpretation. Being outside the risk zone does not necessarily imply that the members of these dyads should be considered "democratic," at least in the fullest, most meaningful sense of the term.

If we use the classification of regimes proposed by Lührmann et al. (2017), which are based on Lindberg (2016), of the two dyads under consideration, Poland was the only liberal democracy of all four participating countries. In fact, Lührmann et al (2017) consider Lithuania in 1920 to

For a careless reader, the predicted probabilities presented here might seem low. Nevertheless, they have similar levels compared to some of the main works in the literature (Russett 1994; Russett and Oneal 2001; Gartzke and Weisiger 2013; Weisiger and Gartzke 2016). Since wars are infrequent events in history, the probability of war or conflict for a given dyad will always be relatively low.

Unlike other studies in the literature, we have considered all dyads in the international system. Although we agree that some dyads have a much lower probability of militarized conflict, the selection of 'relevant dyads' involves arbitrary decisions without a solid theoretical base. Braumoeller \& Carson (2011) are critical of controlling for the political relevance of the dyad, arguing that it eliminates much of the likelihood of conflict, and, for the reasons they state, our work considers all dyads, including those that, due to their distance from each other and their material capacities, have a low (or null) probability of conflict among themselves. This issue has been addressed by Beck et al. (2000) and also King \& Zeng (2001), who address the statistical implications of including or not including these observations. Since part of the literature has used politically relevant dyads to test the democratic peace theory, we run Models 8, 9 and 10 for this subset. See Table B in the Appendix. 
have been an electoral autocracy, and in 1919—when Poland captured Vilnius - a closed autocracy, despite the fact that in 1920 it had a polyarchy score of 0.59 with a confidence interval oscillating between 0.54 to 0.64 .

The conflict between Turkey and Cyprus is less confusing, at least when we consider dichotomous measures of democracy. Despite the fact that according to Lührmann et al. (2017) neither country was a liberal democracy in 1974, they did satisfy the criteria for electoral democracies. Nonetheless, following other measures of democracy-particularly those that set a group of necessary conditions, such as those of Cheibub et al. (2010), Haber and Menaldo (2011), Boix et al. (2013) — Cyprus does not qualify as a democracy in 1974, but Turkey does.

It is crucial to notice that there is no case of a war in any dyad whose democratic level is above 0.61 using the V-DEM polyarchy score. Of course, as V-DEM's measurement model is based on Bayesian item response theory (IRT) modeling techniques to estimate the latent characteristics of its collection of expert ratings (Pemstein et al. 2015), it should not be a surprise that some dyads change their democratic scores for the same year in different versions of the data. In other words, the measurement model is constantly readjusting itself once new waves of data come in. Moreover, because the values for each dyad are set relative to all other dyads, one cannot use a value as a threshold but could theorize a certain decile.

Based on our theoretical framework and empirical models, we infer a heuristic that recognizes three large regions of political regimes in relation to the level and democratic spread of any dyad. On the one hand, any pair of countries located at or below the lower quartile [defined by the formula $y=0.5 x+0.25]$, has a substantially greater probability of going to war. As expected, a dyad in the risk area is 40 times more likely to go to war than a dyad that is outside this region. At the same time, while the peace triangle has not predictive power over the probability of war, it has a strong effect on MIDs (dyads in the zone of peace see their probabilities of MID cut in half).

On the other hand, we identify a zone of peace that includes pairs of countries located at or above the sixth decile [defined by the formula $y=0.5 x+0.60$ ]. The three resulting areas can be clearly identified in Figure 3 with dotted lines. This rule should be independent of readjustments of the values in V-DEM data. At the time we did this research, there was no empirical case or war falling on or above this line.

This heuristic rule is in harmony with previous theoretical works, such as Goertz et al. (2016: 27) when they suggest a "peace scale for State relationships." As mentioned, they propose three areas of dyadic conflict, named Rivalry, Negative Peace, and Positive Peace, respectively. The difference here is that while they reach their models through a theoretical analysis, we conduct an 
inductive, data-driven analysis. Nevertheless, their elaboration perfectly overlaps with our findings: Rivalry materialized in our Risk-Region, Positive Peace is equivalent to our Peace Zone, and Negative Peace is represented as the area in between the Peace Zone and Risk-Region.

Thus, proposing a risk area and a zone of peace hypothesis, we test the following model:

$$
\begin{aligned}
\operatorname{Pr}(\text { War })_{\mathrm{i}, \mathrm{t}}= & \beta_{0}+\beta_{1} \text { PeaceZone }_{\mathrm{i}, \mathrm{t}}+\beta_{2} \text { RiskArea }_{\mathrm{i}, \mathrm{t}}+\beta_{3} \text { Contiguity }_{\mathrm{i}} \\
& +\beta_{4}\left(\mathrm{log} \text { Distance }_{\mathrm{i}}+\beta_{5} \text { Alliance }_{\mathrm{i}, \mathrm{t}}+\beta_{6} \text { CINC }_{\mathrm{i}, \mathrm{t}}+\beta_{7} \text { GreatPower }_{\mathrm{i}, \mathrm{t}}\right. \\
& +\beta_{8} \text { TradeInterdependence }_{\mathrm{i}, \mathrm{t}}+\beta_{9 \ldots 11} \text { TimeAutocorrelation }_{\mathrm{i}, \mathrm{t}}
\end{aligned}
$$

As expected, a dyad in the risk area is 40 times more likely to go to war than a dyad that is outside this region (see Model 1). At the same time, while the peace triangle has not predictive power over the probability of war, it has a strong effect on MIDs (dyads in the zone of peace see their probabilities of MID cut to a half). 
Table 3: Zones of Peace and Risk

\begin{tabular}{|c|c|c|c|}
\hline \multirow{3}{*}{ Dependent variable: } & (4) & (5) & (6) \\
\hline & war & $\operatorname{MID}(\mathrm{a})$ & MID (b) \\
\hline & & Ordered & Ordered \\
\hline Model: & Logit & logit & logit \\
\hline \multirow[t]{2}{*}{ Risk Area } & $40.71^{* * *}$ & $1.77^{* * *}$ & $1.76^{* * *}$ \\
\hline & $(3.65)$ & (3.63) & $(3.64)$ \\
\hline \multirow[t]{2}{*}{ Peace Zone } & 0.28 & $0.50^{* * *}$ & $0.50^{* * *}$ \\
\hline & $(-1.70)$ & $(-3.83)$ & $(-3.79)$ \\
\hline \multicolumn{4}{|l|}{ Trade } \\
\hline \multirow[t]{2}{*}{ interdependence } & $0.957 * *$ & $0.967 * * *$ & 0.966 *** \\
\hline & $(-3.00)$ & $(-3.36)$ & $(-3.52)$ \\
\hline \multirow[t]{2}{*}{ Contiguity } & 4.472 & $20.18^{* * *}$ & $19.22 * * *$ \\
\hline & $(1.56)$ & $(21.43)$ & $(20.88)$ \\
\hline \multirow[t]{2}{*}{ Distance (log) } & 0.796 & $0.879 * *$ & $0.875^{* *}$ \\
\hline & $(-1.85)$ & $(-2.89)$ & $(-3.06)$ \\
\hline \multirow[t]{2}{*}{ Material Capabilities } & 709.7 & $49769^{* * *}$ & $42050^{* * *}$ \\
\hline & $(1.44)$ & $(6.19)$ & $(6.33)$ \\
\hline \multirow[t]{2}{*}{ Alliance } & $0.12^{* * *}$ & $0.61 * * *$ & $0.61 * * *$ \\
\hline & $(-3.71)$ & $(-6.14)$ & $(-6.05)$ \\
\hline \multirow{2}{*}{ One is a major power } & 1.281 & 1.134 & 1.136 \\
\hline & $(0.37)$ & $(0.94)$ & $(0.96)$ \\
\hline \multirow[t]{2}{*}{$t$} & 1.134 & 1.002 & 1.003 \\
\hline & $(0.67)$ & $(0.05)$ & $(0.09)$ \\
\hline \multirow[t]{2}{*}{$t^{2}$} & 1.000 & 1.001 & 1.001 \\
\hline & $(-0.13)$ & $(1.39)$ & (1.34) \\
\hline \multirow[t]{2}{*}{$t^{3}$} & 1.000 & $1.000^{*}$ & $1.000^{*}$ \\
\hline & $(-0.51)$ & $(-2.50)$ & $(-2.43)$ \\
\hline AIC & 2719.9 & 18660.6 & 22023.9 \\
\hline Pseudo $\mathrm{R}^{2}$ & 0.182 & 0.243 & 0.214 \\
\hline$\% \mathrm{CP}$ & $99 \%$ & $52 \%$ & $48 \%$ \\
\hline $\mathrm{N}$ & 364507 & 364507 & 364507 \\
\hline
\end{tabular}




\section{Conclusions}

This study suggests, once again, that the premises of democratic peace are strong enough even to withstand radically different measures of democracy. These results are also solid enough to survive alternative ways of operationalizing the dependent variable (war/MID). Democracies do not fight each other, although this does not mean they are necessarily less warlike.

Despite the fact that the democratic peace is probably one of the most revisited theories in international relations, practically all previous studies are based on a single measure of democracy: Polity. Thus, the main objective of this work has been to reconsider this theory using a new, stronger, and more robust measure of democracy, V-DEM's polyarchy index.

Working with a truly continuous measure of polyarchy, this document provides a finer evaluation of the supposedly peaceful behavior of those regimes located in the upper zone of the polyarchy index. Likewise, we manage to avoid using the sort of predetermined, arbitrary distinction between democracies and non-democracies that is a common pitfall in the literature on the subject.

In doing so, we propose an Interactive Model of Democratic Peace that suggests there is an interplay between the democratic mean and democratic spread of the dyads. This interplay creates a triangle of possible outcomes that we call the dyadic triangle. From this model, we derive that the pattern of democratic peace, an empirical law for some colleagues, works differently from what has been predicted by the traditional or the similarity-based views.

Using the interplay between the dyads' mean and spread of democracy, we were able to theoretically and empirically derive three heuristic zones, filling much of the gray-area that has been left unexplained by previous models. Although our model is the first to explore these two dimensions interactively, the Interactive Model still has to keep updating itself (as democracy scores update yearly), filling the blanks (as there is missing data), and moving forward to incorporate more and more dyads characteristics. 


\section{Appendix}

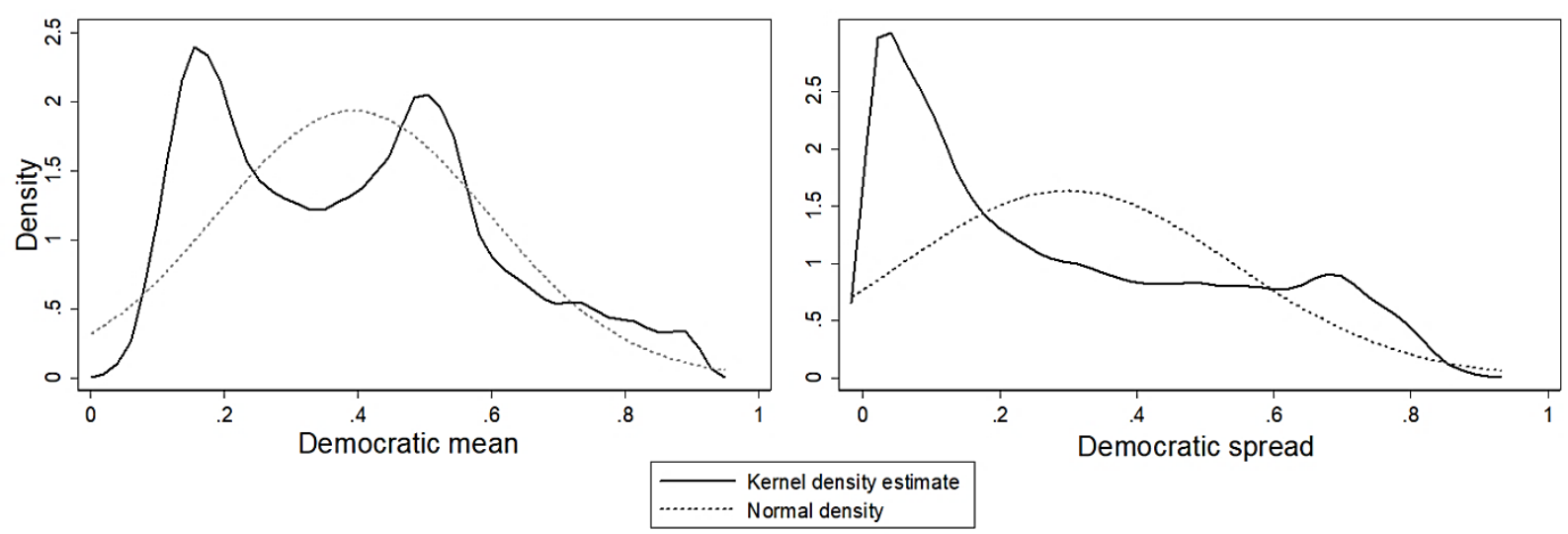

Figure A1: Kernel density of democratic level and spread 


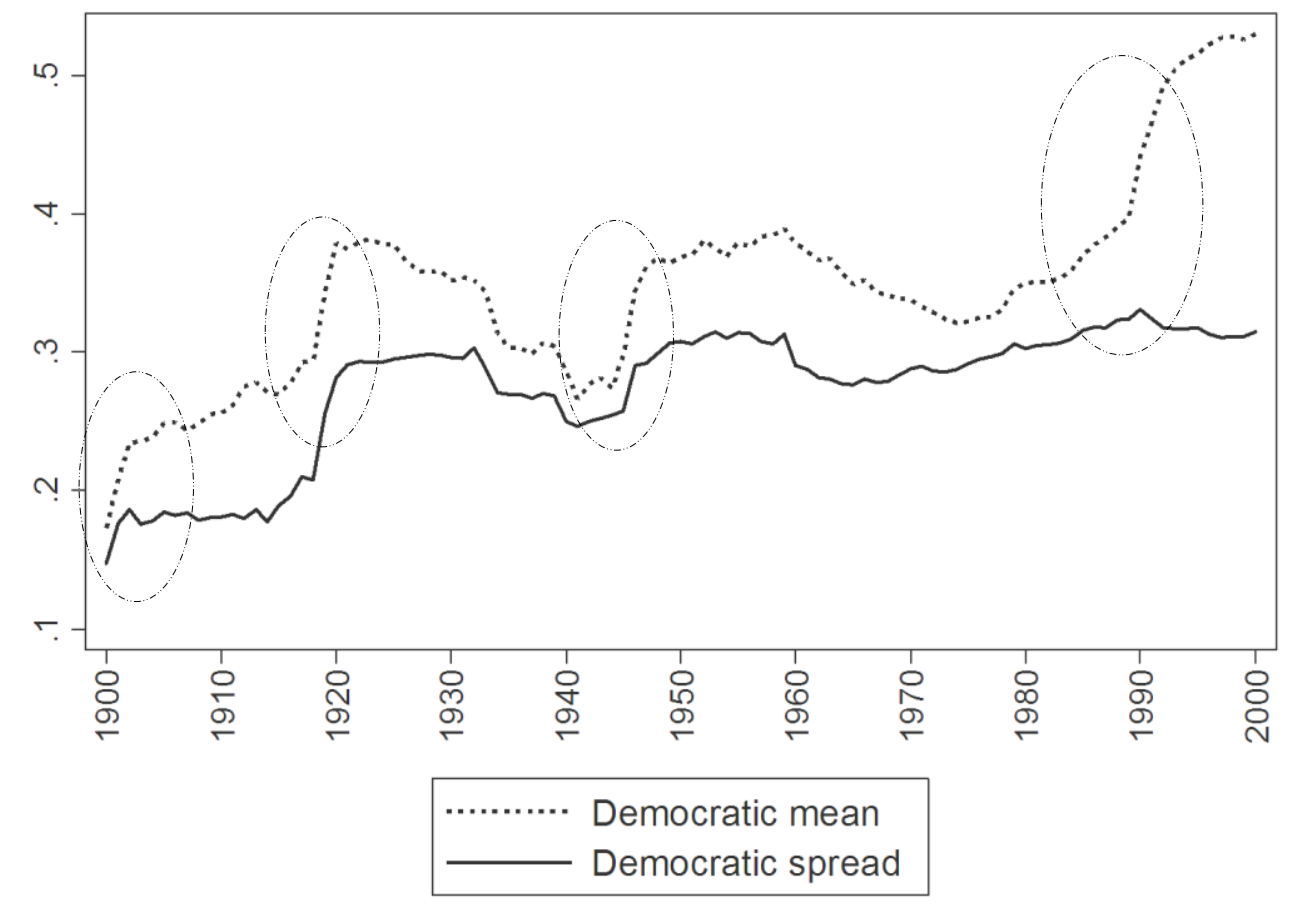

Figure A2: Democratic mean and spread in time 


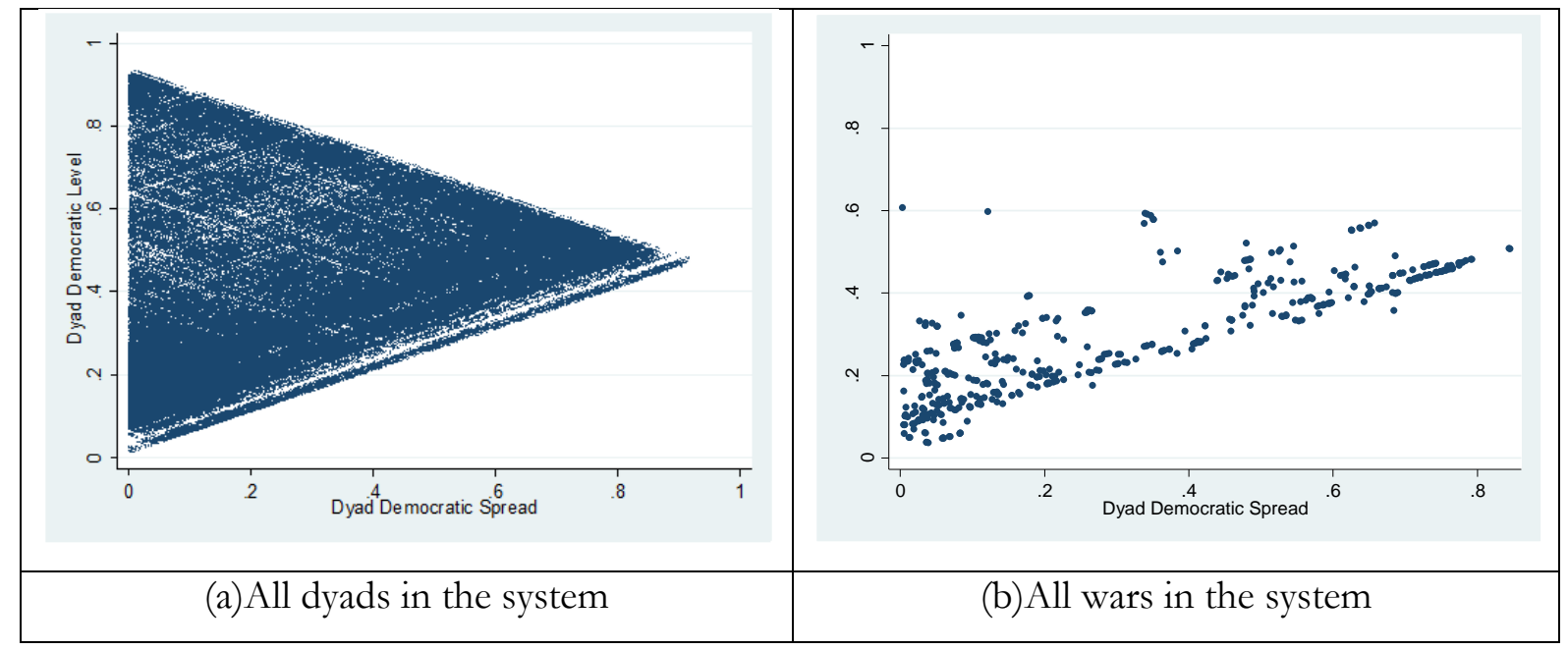

Figure A3: Distribution of all dyads in the system and all dyads at war based on dyad's democratic level and spread 


\section{Robustness Checks}

Table A: Robustness check A - Rare Events Logit

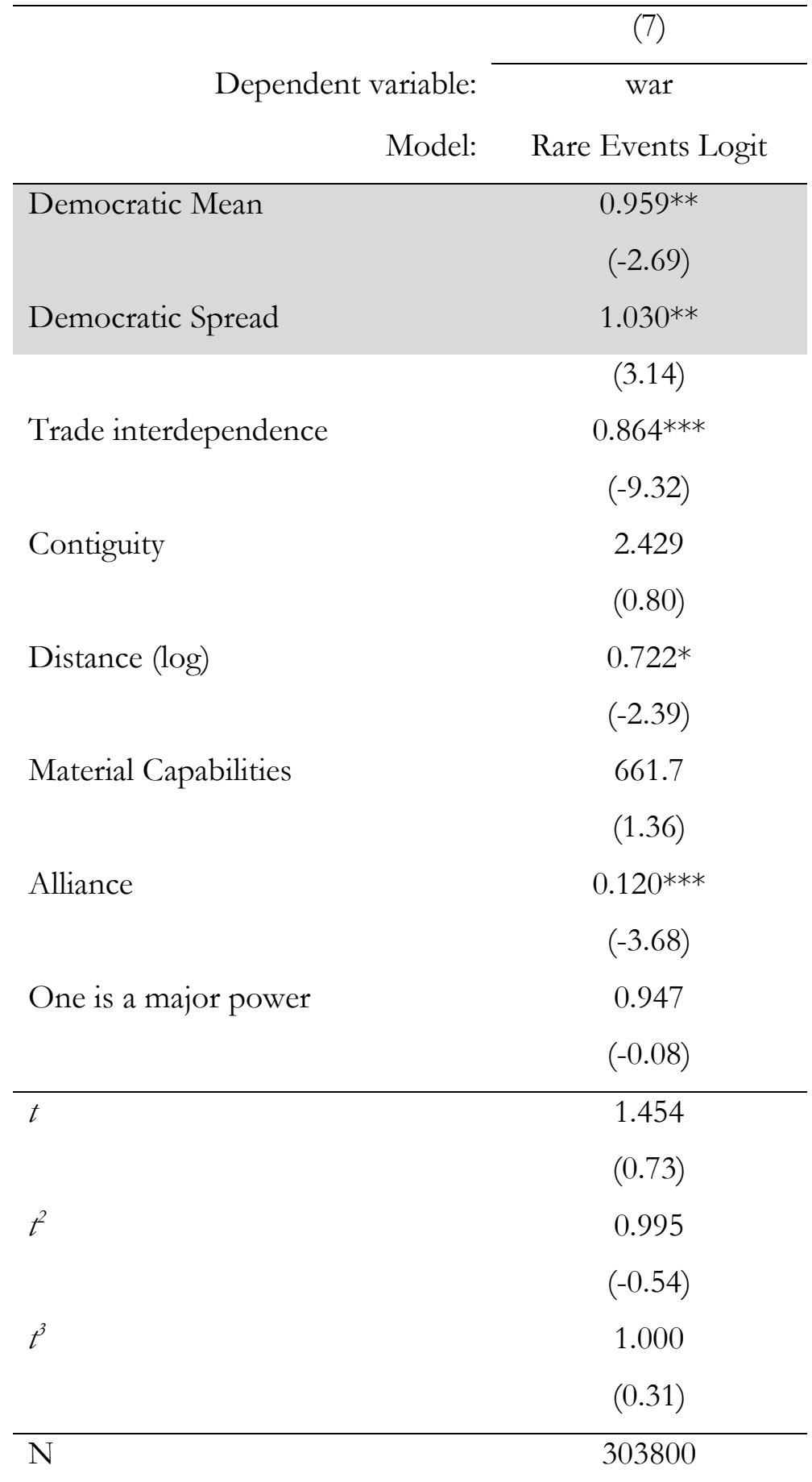

Coefficients expressed as odds ratios; Standard errors

clustered in dyads. t statistics in parentheses; ${ }^{*} \mathrm{p}<0.05,{ }^{* *}$ $\mathrm{p}<0.01, * * * \mathrm{p}<0.001$ 
Table B: Robustness check B - Politically relevant dyads

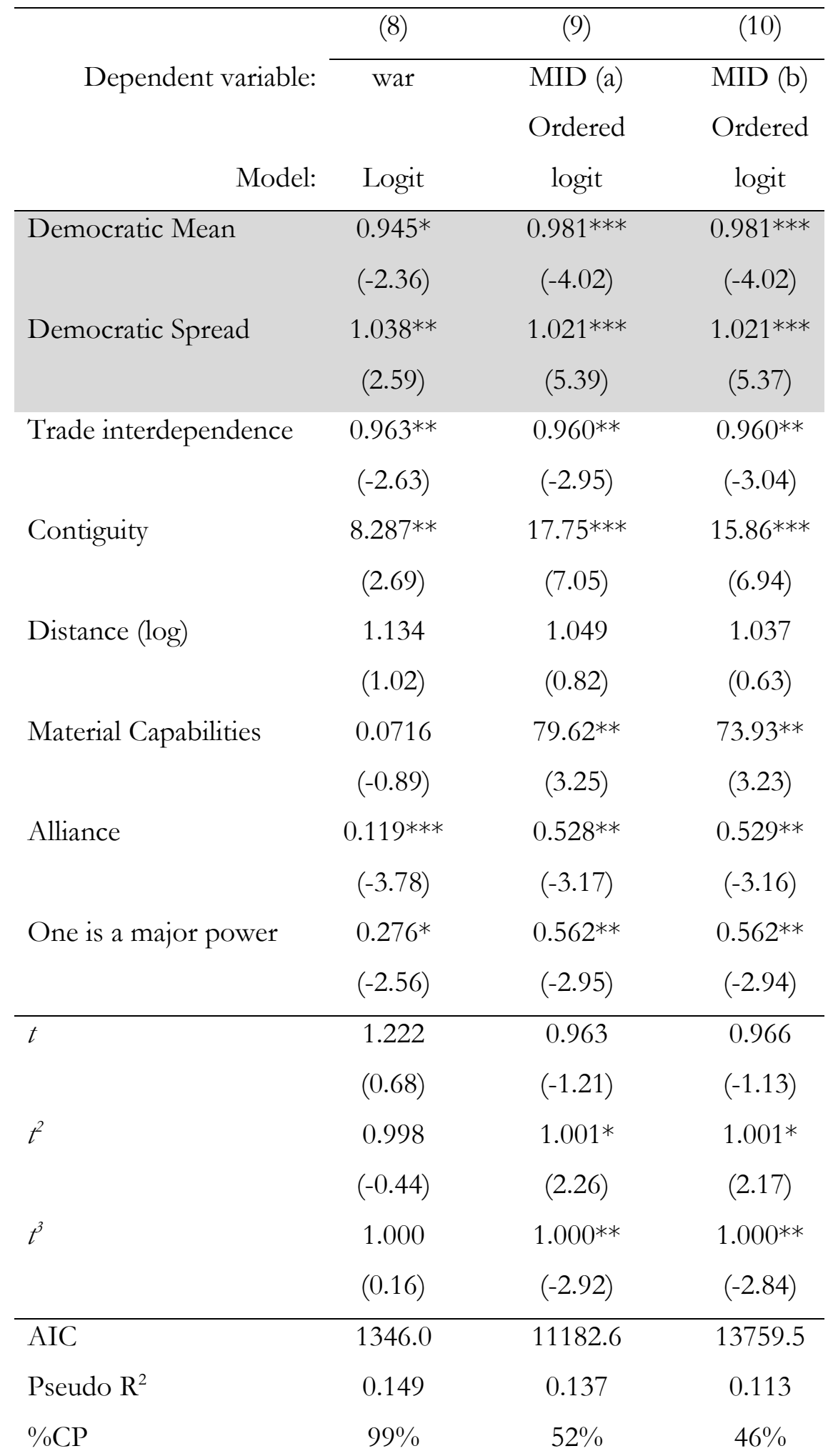


Coefficients expressed as odds ratios; Standard errors clustered in dyads; t statistics in parentheses; ${ }^{*} \mathrm{p}<0.05,{ }^{* *} \mathrm{p}<0.01,{ }^{* * *} \mathrm{p}<0.001$ 


\section{References}

Agresti, Alan. 2007. An Introduction to Categorical Data Analysis. 2nd ed. Hoboken: Wiley.

Babst, Dean. 1964. "Elective Governments - a Force for Peace." The Wisconsin Sociologist 3 (1):914.

Barbieri, Katherine, and Richard Alan Peters. 2003. "Measure for Mis-Measure: A Response to Gartzke \& Li." Journal of Peace Research 40 (6):713-9.

Barkawi, Tarak, and Mark Laffey. 1999. "The Imperial Peace: Democracy, Force and Globalization." European Journal of International Relations 5 (4):403-34.

Beck, Nathaniel, Gary King, and Langche Zeng. 2000. "Improving Quantitative Studies of International Conflict: A Conjecture." American Political Science Review 94 (1):21-35.

Bennett, Scott. 2006. "Toward a Continuous Specification of the Democracy-Autocracy Connection." International Studies Quarterly 50 (2):313-38.

Bernhard, Michael, Ömer Faruk Örsün, and Reşat Bayer. 2017. "Democratization in Conflict Reaserch: How Conceptualization Affects Operationalization and Testing Outcomes." International Interactions 43 (6):941-66.

Berry, William D, Jacqueline HR DeMeritt, and Justin Esarey. 2010. "Testing for Interaction in Binary Logit and Probit Models: Is a Product Term Essential?" American Journal of Political Science 54 (1):248-66.

Blaney, David L. 2001. "Realist Spaces/Liberal Bellicosities: Reading the Democratic Peace as World Democratic Theory." In Democracy, Liberalism, and War: Rethinking the Democratic Peace Debates, ed. T. Barkawi and M. Laffey. Boulder, Co.: Lynne Rienner Publishers.

Bogaards, Matthijs 2012. "Where to Draw the Line? From Degree to Dichotomy in Measures of Democracy." Democratization 19 (4):690-712.

Boix, Carles, Michael Miller, and Sebastian Rosato. 2013. "A Complete Data Set of Political Regimes, 1800-2007." Comparative Political Studies 46 (12):1523-54.

Braumoeller, Bear F, and Austin Carson. 2011. "Political Irrelevance, Democracy, and the Limits of Militarized Conflict." Journal of Conflict Resolution 55 (2):292-320.

Bremer, Stuart. 1992. "Dangerous Dyads: Conditions Affecting the Likelihood of Interstate War, 1816-1965." Journal of Conflict Resolution 36 (2):309-41.

Bremer, Stuart, J. David Singer, and John Stuckey. 1972. "Capability Distribution, Uncertainty, and Major Power War, 1820-1965." ed. B. M. Russett. London: Sage. 
Brown, Michael. 1999. Debating the Democratic Peace: An International Security Reader. Cambridge: MIT University Press.

Carter, David B., and Curtis S. Signorino. 2010. "Back to the Future: Modeling Time Dependence in Binary Data." Political Analysis 18 (3):271-92.

Castiglioni, Rossana. 2001. "The Politics of Retrenchment: The Quandaries of Social Protection Under Military Rule in Chile 1973-1990." Latin American Politics \& Society 43 (4):37-66.

Chan, Steve. 1984. "Mirror, Mirror on the Wall...Are the Freer Countries More Pacific?" Journal of Conflict Resolution 28 (4):617-48.

Cheibub, José Antonio, Jennifer Gandhi, and James Raymond Vreeland. 2010. "Democracy and Dictatorship Revisited." Public Choice 143 (1-2):67-101.

Coppedge, Michael, John Gerring, David Altman, Michael Bernhard, Steven Fish, Allen Hicken, Matthew Kroenig, Staffan I. Lindberg, Kelly McMann, Pamela Paxton, Holli A. Semetko, Svend-Erik Skaaning, Jeffrey Staton, and Jan Teorell. 2011. "Conceptualizing and Measuring Democracy: A New Approach." Perspectives on Politics 9 (2):247-67.

Coppedge, Michael, John Gerring, Staffan I. Lindberg, Svend-Erik Skaaning, Jan Teorell, Joshua Krusell, Kyle L. Marquardt, Valeriya Mechkova, Daniel Pemstein, Josefine Pernes, Laura Saxer, Natalia Stepanova, Eitan Tzelgov, Yi-ting Wang, and Steven Wilson. 2017. V-Dem Methodology v7. Varieties of Democracy (V-Dem) Project.

Coppedge, Michael, John Gerring, Staffan I. Lindberg, Svend-Erik Skaaning, Jan Teorell, David Altman, Michael Bernhard, M. Steven Fish, Adam Glynn, Allen Hicken, Carl Henrik Knutsen, Kelly McMann, Pamela Paxton, Daniel Pemstein, Jeffrey Staton, Rachel Sigman, Brigitte Zimmerman, Frida Andersson, Valeriya Mechkova, and Farhad Miri. 2016a. V-Dem Codebook v6. Varieties of Democracy (V-Dem) Project.

Coppedge, Michael, Staffan I. Lindberg, Svend-Erik Skaaning, and Jan Teorell. 2016b. "Measuring High Level Democratic Principles Using the V-Dem Data." International Political Science Review 37 (2):580-93.

Dafoe, Allan. 2011. "Statistical Critiques of the Democratic Peace: Caveat Emptor." American Journal of Political Science 55 (2):247-62.

Dafoe, Allan, John Oneal, and Bruce Russett. 2013. "The Democratic Peace: Weighing the Evidence and Cautious Inference." International Studies Quarterly 57 (1):201-14.

Dahl, Robert A. 1971. Polyarchy: Participation and Opposition. New Haven: Yale University Press. 1989. Democracy and Its Critics. New Haven: Yale University Press. 
Dixon, William J. 1994. "Democracy and the Peaceful Settlement of International Conflict." American Political Science Review 88 (1):14-32.

Doyle, Michael. 1986. "Liberalism in World Politics." American Political Science Review 80 (4):115169.

Gandhi, Jennifer. 2008. Political Institutions under Dictatorship. New York: Cambridge University Press.

Gartzke, Erik. 1998. "Kant We All Get Along?: Opportunity, Willingness, and the Origins of the Democratic Peace." American Journal of Political Science 42 (1):1-27.

_. 2000. "Preferences and the Democratic Peace." International Studies Quarterly 44 (2):191210.

—. 2007. "The Capitalist Peace." American Journal of Political Science 51 (1):166-91.

Gartzke, Erik, and Alex Weisiger. 2013. "Permanent Friends? Dynamic Difference and the Democratic Peace." International Studies Quarterly 57 (1):171-85.

Gibler, Douglas M. 2008. International Military Alliances, 1648-2008. Washington DC: CQ Press.

Gleditsch, Nils Petter. 1992. "Democracy and Peace." Journal of Peace Research 29 (4):369-76.

Gleditsch, Nils Petter, and Håvard Hegre. 1997. "Peace and Democracy: Three Levels of Analysis." Journal of Conflict Resolution 41 (2):283-310.

Goertz, Gary. 2017. Multimethod Research, Causal Mechanisms, and Case Studies: An Integrated Approach. Princeton: Princeton University Press.

Goertz, Gary, Paul F. Diehl, and Alexandru Balas. 2016. The Puzzle of Peace: The Evolution of Peace in the International System. New York: Oxford University Press.

Haber, Stephen, and Victor Menaldo. 2011. "Do Natural Resources Fuel Authoritarianism? A Reappraisal of the Resource Curse." American Political Science Review 105 (1):1-26.

Hegre, Håvard. 2014. "Democracy and Armed Conflict." Journal of Peace Research 51 (2):159-72.

Hegre, Håvard, Michael Bernhard, and Jan Teorell. Forthcoming. "Constraint and the Democratic Peace: Explaining Inter-State Armed Conflict, 1900-2010."

Henderson, Errol Anthony. 2002. Democracy and War: The End of an Illusion? Boulder, CO: Lynne Rienner Publishers.

Hensel, Paul R. 2000. "Territory: Theory and Evidence on Geography and Conflict." In What do We Know about War, ed. J. A. Vasquez. New York: : Rowman \& Littlefield.

Hewitt, J. Joseph, and Jonathan Wilkenfeld. 1996. "Democracies in International Crisis." International Interactions 22 (2):123-42. 
Ishiyama, John, Ryan Conway, and Katherine Haggans. 2008. "Is there a Monadic Authoritarian Peace: Authoritarian Regimes, Democratic Transition Types and the First Use of Violent Force." African Journal of Political Science and International Relations 2 (3):31-7.

Jones, Daniel, Stuart Bremer, and David Singer. 1996. "Militarized Interstate Disputes, 18161992: Rationale, Coding Rules, and Empirical Patterns." Conflict Management and Peace Science 15 (2):163-213.

King, Gary, Robert Keohane, and Sidney Verba. 1994. Designing Social Inquiry: Scientific Inference in Qualitative Research. Princeton: Princeton University Press.

King, Gary, and Langche Zeng. 2001. "Logistic Regression in Rare Events Data." Political Analysis 9 (2):137-63.

Lake, David. 1992. "Powerful Pacifists: Democratic States and War." American Political Science Review 86 (1):24-37.

Lektzian, David, and Mark Souva. 2009. "A Comparative Theory Test of Democratic Peace Arguments, 1946-2000." Journal of Peace Research 46 (1):17-37.

Levy, Jack S. 1989. "The Causes of War: A Review of Theories and Evidence." In Behavior, Society, and Nuclear War, vol. 1, ed. Philip E. Tetlock, Jo L. Husbands, Robert Jervis, Paul C. Stern and Charles Tilly. New York: Oxford University Press.

- 2002. "War and Peace." In Handbook of International Relations, ed. W. Carlsnaes, Thomas Risse and Beth Simmons. Thousand Oaks, CA: Sage Publications.

Levy, Jack S., and Gary Goertz, eds. 2007. Explaining W ar and Peace: Case Studies and Necessary Condition Counterfactuals. Edited by C. S. Studies. New York: Routledge.

Lindberg, Staffan I. 2016. "Ordinal Versions of V-Dems Indices: When Interval Measures are not Useful for Classification, Description, and Sequencing Analysis Purposes." Geopolitics, History, and International Relations 8 (2):76-111.

Long, J. Scott, and Jeremy Freese. 2006. Regression Models for Categorical Dependent Variables using Stata. College Station: Stata Press.

Long, J.Scott. 1997. Regression Models for Categorical and Limited Dependent Variables. California: SAGE Publications.

Lührmann, Anna, Staffan I. Lindberg, and Marcus Tannenberg. 2017. "Regimes In the World (RIW): A Robust Regime Type Measure based on V-Dem." The Varieties of Democracy Institute Working Paper 47 (May).

Mansfield, Edward D. 1988. "The Distribution of Wars Over Time." World Politics 41 (1):21-51. 
Maoz, Zeev. 1999. "Dyadic Militarized Interstate Disputes (DYMID1. 1) Dataset, version 1.1.". Computer File. Tel-Aviv University.

Maoz, Zeev, and Nasrin Abdolali. 1989. "Regime Types and International Conflict, 1816-1976." Journal of Conflict Resolution 33 (1):3-35.

Maoz, Zeev, and Bruce Russett. 1993. "Normative and Structural Causes of Democratic Peace, 1946-1986." American Political Science Review 87 (3):624-38.

Mousseau, Michael. 2009. "The Social Market Roots of Democratic Peace." International Security 33 (4):52-86.

—. 2013. "The Democratic Peace Unraveled: It's the Economy " International Studies Quarterly 57 (1):186-97.

Munck, Gerardo L., and Jay Verkuilen. 2002. "Conceptualizing and Measuring Democracy: Evaluating Alternative Indices." Comparative Political Studies 35 (1):5-34.

Oneal, John R., and Bruce M. Russet. 1997. "The Classical Liberals were Right: Democracy, Interdependence, and Conflict, 1950-1985." International Studies Quarterly 41 (2):267-94.

Oneal, John R., and Bruce M. Russett. 2015. "The Kantian Peace: The Pacific Benefits of Democracy, Interdependence, and International Organizations, 1885-1992." In Bruce M. Russett: Pioneer in the Scientific and Normative Study of War, Peace, and Policy, ed. H. Starr. London: Springer International Publishing.

Peceny, Mark, Caroline C. Beer, and Shannon Sanchez-Terry. 2002. "Dictatorial Peace?" American Political Science Review 96 (1):15-26.

Pemstein, Daniel, Kyle L. Marquardt, Eitan Tzelgov, Yi-ting Wang, and Farhad Miri. 2015. "The V-Dem Measurement Model: Latent Variable Analysis for Cross-National and CrossTemporal Expert-Coded Data." Varieties of Democracy Institute - University of Gothenburg Working Paper No. 21.

Pickering, Jeffrey. 2002. "Give Me Shelter: Reexamining Military Intervention and the Monadic Democratic Peace." International Interactions 28 (4):293-324.

Rainey, Carlisle. 2016. "Compression and Conditional Effects: A Product Term is Essential when Using Logistic Regression to Test for Interaction." Political Science Research and Methods 4 (3):621-39.

Raknerud, Arvid, and Håvard Hegre. 1997. "The Hazard of War: Reassessing the Evidence for the Democratic Peace." Journal of Peace Research 34 (4):385-404.

Ray, James Lee. 2003. "Explaining Interstate Conflict and War: What Should Be Controlled 
For?" Conflict Management and Peace Science 20 (2):1-32.

Rosato, Sebastian. 2003. "The Flawed Logic of Democratic Peace Theory." American Political Science Review 97 (4):585-602.

Rummel, Rudolph. 1983. "Libertarianism and International Violence." Journal of Conflict Resolution 27 (1):27-71.

Russett, Bruce. 1990. Controlling the Sword: The Democratic Governance of National Security. Cambridge, MA: Harvard University Press.

— 1994. Grasping the Democratic Peace: Principles for a Post-Cold War World. Princeton NJ: Princeton University Press.

Russett, Bruce, and John Oneal. 2001. Triangulating Peace, Democracy, Interdependence, and International Organizations. New York: Norton.

Senese, Paul D. 2005. "Territory, Contiguity, and International Conflict: Assessing a New Joint Explanation." American Journal of Political Science 49 (4):769-79.

Singer, J. David. 1988. "Reconstructing the Correlates of War Dataset on Material Capabilities of States, 1816-1985." International Interactions 14 (2):115-32.

Singer, J. David, and Melvin Small. 1966. "Formal Alliances, 1815-1939: A Quantitative Description." Journal of Peace Research 3 (1):1-31.

- 1974. "Foreign Policy Indicators: Predictors of War in History and in the State of the World Message." Policy Sciences 5 (3):271-96.

Small, Melvin, and J. David Singer. 1969. "Formal Alliances, 1816-1965: An Extension of the Basic Data." Journal of Peace Research 6 (3):257-82.

Spiro, David E. 1994. "The Insignificance of the Liberal Peace." International Security 19 (2):5086.

Weisiger, Alex, and Erik Gartzke. 2016. "Debating the Democratic Peace in the International System." Harvard Dataverse.

Werner, Suzanne. 2000. "The Effects of Political Similarity on the Onset of Militarized Disputes, 1816-1985." Political Research Quarterly 53 (2):343-74. 